\title{
PENGGUNAAN STORYTELLING UNTUK MENINGKATKAN KESIAPAN UNTUK BERUBAH PADA KARYAWAN
}

\section{USE STORYTELLING TO INCREASE READINESS FOR CHANGE AMONG TELECOMMUNICATION ENTERPRISE EMPLOYEES}

\author{
Endang Veronica Br Silangit \\ Haryanto FR \\ Fakultas Psikologi Universitas Gadjah Mada Yogyakarta \\ Email: haryo_gebang@yahoo.co.id
}

\begin{abstract}
This research aims to investigate whether the use of storytelling may increase readiness for change among telecommunication enterprise employees. Storytelling was designed to deliver five massages of change to employees. Subjects in this research were the employees of telecommunication of Jogjakarta. Subjects were categorized into two groups, the first is the experimental group, and the second is the control group, which both groups consisted of 10 subjects. The experimental group was given storytelling for five times and the control group was not given any intervention. The experiment design used the untreated pretest-posttest control group design (Shadish, Cook \& Campbell, 2002). The data were analyzed with Wilcoxon-Signed Rank test. It showed that storytelling was able to increase the readiness for change among employees ( $\mathrm{z}=-$ $2,197, p=<0,05)$.
\end{abstract}

Keywords: massages of change, storytelling, readiness for change

\section{ABSTRAK}

Penelitian ini bertujuan untuk mengetahui apakah penggunaan storytelling mampu meningkatkan kesiapan untuk berubah karyawan. Storytelling digunakan untuk menyampaikan lima komponen pesan perubahan pada karyawan. Subjek dalam penelitian ini adalah karyawan perusahaan industri telekomunikasi wilayah Yogyakarta. Subjek dibagi dalam dua kelompok yaitu kelompok eksperimen dan kelompok kontrol dimana masing-masing kelompok berjumlah 10 orang. Kelompok eksperimen diberikan storytelling sebanyak lima kali pertemuan, sedangkan kelompok kontrol tidak diberikan perlakuan. Rancangan eksperimen menggunakan untreated pretest-posttest control group design (Shadish, Cook \& Campbell, 2002). Data yang diperoleh dianalisis melalui uji Wilcoxon Signed-Rank Test. Hasil menunjukkan bahwa storytelling efektif untuk meningkatkan kesiapan untuk berubah $(z=-2.197, p<0,05)$.

Kata kunci: pesan perubahan, storytelling, kesiapan untuk berubah

Sekarang ini BUMN dituntut tidak hanya sekedar dapat bertahan hidup, tetapi juga harus memperoleh profit. Tuntutan ini sesuai dengan peran BUMN sendiri, seperti tertuang dalam UU N0.19/2003 tentang Badan Usaha Milik Negara $(B \cup M N)$, yaitu berperan penting dalam penyelenggaraan perekonomian nasional, guna mewujudkan kesejahteraan masyarakat. Berkaitan dengan hal tersebut, BUMN harus dapat menyediakan barang dan/atau jasa yang bermutu tinggi dan berdaya saing kuat, mengejar keuntungan guna meningkatkan nilai perusahaan dan 
menyelenggarakan usaha yang bertujuan untuk kemanfaatan umum berupa penyediaan barang dan/atau jasa yang berkualitas dengan harga yang terjangkau oleh masyarakat berdasarkan prinsip pengelolaan yang sehat (Sugiharto, 2005).

Hal ini disadari penuh oleh jajaran manajemen industri telekomunikasi bahwa untuk mampu bersaing dengan kompetitor dalam bisnis yang serupa, maka mereka harus berbenah. Perusahaan harus berani berubah sesuai dengan tuntutan pasar. Untuk menjawab tantangan lingkungan bisnis tersebut, maka manajemen melakukan transformasi bisnis secara fundamental yang diikuti dengan diperkenalkannya corporate identity baru untuk menyambut era baru, yaitu menjadi satu-satunya perusahaan TIME (Telecommunication, Information, Media and Edutainment) di Indonesia. Untuk itu, sejak beberapa tahun lalu perusahaan mulai menggeser portofolio bisnisnya dari bidang informasi dan komunikasi ke bidang apa yang disebut sebagai TIME (Telecommunication Information, Media dan Edutainment). Kini perusahaan mengurusi saluran telepon, internet, pelayaan informasi teknologi, televisi berbayar, serta layanan konten interaktif baik untuk keperluan bisnis, hiburan maupun pendidikan.

Corporate identity berubah menjadi TIME (Telecommunication, Information, Media and Edutainment) disertai dengan dilakukannya perubahan-perubahan dalam diri perusahaan. Perubahan-perubahan tersebut antara lain (1) perubahan pada logo perusahaan. (2) perubahan budaya (culture) yakni commitment, spirit, promise, product and service quality serta service culture. (3) perubahan positioning, yaitu life confident yang artinya perusahaan mendedikasikan keahlian yang dimilikinya kepada kemajuan, sehingga akan memberikan keyakinan bagi semua pelanggan untuk mendukung kehidupan mereka di mana pun mereka berada. (4) perubahan nilai yaitu merumuskan nilai baru yang dianut perusahaan, yaitu expertise, empowering, assured, progressive and heart dan terakhir adalah perubahan dengan tagline yang baru, yaitu the world in your hand.

Untuk mendukung perubahan portofolio bisnisnya tersebut, perusahaan melakukan transformasi empat aspek paling mendasar perusahaan, yakni transformasi bisnis, transformasi infrastruktur, transformasi sistem dan model operasi serta transformasi sumber daya manusia. Perubahan menyangkut dari satu tahap menuju tahap selanjutnya atau adanya perubahan struktur dan menghasilkan sesuatu yang baru (Chonko, 2004).

Perubahan organisasi meliputi tiga fase proses perubahan. Fase pertama adalah fase persiapan atau kesiapan, dimana pada fase ini anggota organisasi bersiap untuk berubah dan idealnya mendukung perubahan tersebut. Fase kedua adalah adopsi, yakni perubahan diimplementasikan dan karyawan mengadopsi cara-cara baru dalam melakukan pekerjaannya. Fase ini masih fase uji coba sehingga karyawan masih dapat memilih untuk menerima atau menolak perubahan tersebut. Fase terakhir yaitu institualisasi, di mana berge-rak dari usaha menjaga keberhasilan proses adopsi dan memberi- 
kan imbalan dari kesuksesan perubahan hingga perubahan tersebut terinternalisasi (Armenakis, dkk. 1999 dalam Armenakis dan Harris, 2002).

\section{TINJAUAN PUSTAKA}

\section{Kesiapan Berubah}

Beer dan Noria (2000) menyatakan ketika suatu organisasi memutuskan untuk mengadakan perubahan, tantangan yang muncul adalah bagaimana mengelola perubahan itu. Diperkirakan sekitar 70 persen dari usaha perubahan mengalami kegagalan. Hal ini disebabkan berdasarkan literatur perubahan menyebabkan perasaan terancam, ketidakpastian, frustrasi, keadaan yang asing dan kecemasan dalam diri karyawan (Ashford, 1998). Perubahan dalam organisasi biasanya menciptakan perasaan tak pasti dan kecemasan dalam diri karyawan karena situasi yang tidak jelas dan tidak diketahui. Hal yang sama juga dijelaskan oleh Devos, Vanderheyden dan Broek (2002) bahwa sa-lah satu alasan mendasar mengapa upaya perubahan organisasi sangat sulit dicapai adalah faktor individu dalam organisasi. Memotivasi individu untuk melakukan perubahan tidak mudah dilaksanakan, tetapi menjadi aspek penting dari proses persiapan perubahan (Luecke, 2003).

Cummings dan Worley (2005) serta Kotter (1995) menjelaskan definisi kesiapan untuk berubah berarti membuat anggota organisasi yang merasa tidak puas akan keadaan saat ini, dan termotivasi untuk mencoba sesuatu yang baru seperti proses kerja baru, teknologi, ataupun cara ber- perilaku yang baru. Penciptaan kesiapan untuk berubah meliputi juga usaha proaktif yang dilakukan oleh agen perubahan untuk mempengaruhi keyakinan, sikap dan intensi anggota organisasi. Hal ini terjadi karena kesiapan tercermin dalam keyakinan, sikap dan intensi yang berkenaan dengan perubahan-perubahan yang diperlukan dan berkenaan dengan kapasitas organisasi untuk membuat perubahan tersebut berhasil (Armenakis dkk, 1993).

Kesiapan untuk berubah dimulai dari persepsi individu tentang manfaat dari perubahan (Prochaska dkk, dalam Charles \& Shivers-Blackwell, 2006), resiko dari kegagalan perubahan (Armenakis dkk, 1993; Beer, 1980; Spector, dalam Charles dan Shivers-Blackwell, 2006) atau permintaan dari luar yang memaksa untuk berubah (Pettigrew, dalam Charles \& Shivers-Blackwell, 2006). Persepsi individu terhadap manfaat dari perubahan merupakan inisiator terhadap kesiapan untuk berubah (Cunningham, Woodward, Shannon, \& MacIntosh, 2002). Hal ini berarti bahwa jika individu percaya bahwa perubahan bermanfaat untuk mereka, maka mereka akan bersedia untuk berpartisipasi dalam perubahan tersebut.

Armenakis, Harris dan Field (Armenakis dan Harris, 2002) percaya bahwa kesiapan untuk berubah diciptakan melalui penyampaian pesan perubahan yang dilakukan oleh manajemen kepada karyawan. Pengenalan perubahan baru dapat menyebabkan ketidakpastian dan mempengaruhi pola pikir anggota organisasi di masa depan. Pesan perubahan 
biasanya ditujukan untuk menjawab dua hal tersebut dengan menjawab lima pertanyaan kunci. Kelima pertanyaan kunci tersebut dikenal dengan istilah lima komponen utama pesan perubahan. Armenakis, Harris dan Field (Armenakis \& Harris (2002) menyebutkan lima elemen utama dari pesan perubahan yaitu:

Pertama: Discrepancy. Pesan berisikan keadaan organisasi sekarang dan keadaan organisasi yang diharapkan. Dipaparkan adanya kesenjangan antara keadaan sekarang dan keadaan ideal sehingga organisasi membutuhkan perubahan. Jadi individu dimotivasi untuk melakukan perubahan.

Kedua: Efficacy. Pesan meyakinkan individu bahwa mereka mampu melakukan perubahan. Individu dan grup memiliki kemampuan untuk mensukseskan perubahan.

Ketiga: Appropriate. Pesan harus mampu menggambarkan perubahan terjadi adalah tepat sehingga semua individu terlibat dalam perubahan.

Keempat: Principal Support. Pesan menggambarkan dukungan serta usaha pimpinan kunci dalam organisasi untuk mensukseskan perubahan.

Kelima: Personal valence. Pesan berisikan tentang apa manfaat/keuntungan baik intrinsik maupun ekstrinsik dalam perubahan bagi individu.

Kebutuhan akan perubahan menjadi motivasi bagi anggota organisasi untuk mendukung perubahan. Kebutuhan perubahan ini dirasakan oleh anggota organisasi jika mereka melihat adanya ancaman terhadap keberadaan dan kelangsungan hidup perusahaan (Vithessonthi,
2005). Dengan mengidentifikasi faktorfaktor dari kesiapan untuk berubah akan dapat membantu pimpinan organisasi untuk mengimplementasikan perubahan secara efektif. Holt, Achilles, Hubert dan Stanley (2007) dalam penelitiannya untuk membangun pertanyaan-pertanyaan yang digunakan untuk mengukur variabel kesiapan untuk berubah menemukan bahwa efikasi diri untuk berubah, kesesuaian perubahan, dukungan pimpinan dalam proses perubahan, dan manfaat perubahan bagi individu memiliki pengaruh yang signifikan terhadap kesiapan berubah.

Kelima faktor yang berpengaruh terhadap kesiapan berubah tersebut merupakan hasil penggabungan dari literatur dan instrumen kesiapan berubah yang sudah dikumpulkan oleh peneliti, serta ditambahkan dengan interview dan kuesioner yang diberikan kepada manager pada sektor private dan sektor publik. Holt dkk (2007) dalam penelitiannya menyatakan bahwa dalam mengembangkan alat pengukuran kesiapan untuk berubah, hal ini dipengaruhi oleh beberapa faktor, yaitu (1) Kesesuaian perubahan bagi organisasi, hal ini meliputi dua aspek yaitu a) kebutuhan untuk berubah di mana anggota menilai perlu atau tidaknya sebuah organisasi untuk melakukan perubahan dan manfaat perubahan untuk organisasi di mana anggota merasa bahwa perubahan yang akan dilakukan memberikan manfaat bagi organisasi. (2) Dukungan dari pimpinan, yaitu anggota merasa bahwa pimpinan memberikan dukungan terhadap proses perubahan. (3) Manfaat perubahan bagi anggota, yaitu anggota 
merasa perubahan akan memberikan manfaat bagi dirinya. (4) Efikasi diri, yaitu anggota merasa bahwa dirinya bisa melaksanakan proses perubahan dengan baik dan akan berhasil.

Berdasarkan penjelasan di atas dapat ditarik kesimpulan adalah untuk menciptakan kesiapan untuk berubah pada anggota organisasi kelima komponen utama pesan perubahan tersebut harus tersampaikan dengan baik. Komunikasi yang efektif dapat mempengaruhi kesiapan melalui peran informasi tentang perubahan, menciptakan semangat komunitas dan mengurangi tingkat ketidakpastian dan perasaan tidak aman atas pekerjaan (Elving, 2005).

Klein (1996) menyatakan bahwa komunikasi tatap muka dengan penerima pesan perubahan lebih efektif digunakan untuk menyampaikan pesan perubahan. Komunikasi dan interaksi antara implementator dan penerima perubahan dibutuhkan untuk menjadikan perubahan menjadi nyata. Bersama-sama mereka mendiskusikan konsekuensi praktis dan usaha-usaha apa yang dibutuhkan untuk mendukung perubahan. Kolaborasi dalam perubahan akan mendorong ke respon yang positif terhadap perubahan tersebut (Weick \& Quinn, 1999) dan orang-orang akan lebih antusias dan komit terhadap perubahan (Chawla \& Kelloway, 2004). Keterlibatan karyawan akan menstimulasi pertukaran ide-ide dan menciptakan interaksi yang berarti dalam perubahan. Berdasarkan penjelasan di atas dapat disimpulkan bahwa kesiapan untuk berubah diciptakan melalui pengkomunikasian pesan perubahan kepada karyawan dilakukan secara tepat dan efektif sehingga karyawan memahami dengan baik pesan-pesan perubahan yang disampaikan.

\section{Storytelling}

Storytelling merupakan salah satu bentuk berkomunikasi (Bhirud dkk, dalam Gumus, 2007). Storytelling merupakan bentuk pokok dari komunikasi yang sederhana, mudah dimengerti dan efektif (Parkin, dalam Bullock, 2005). Morgan dan Dennehy (1997) menyatakan bahwa storytelling dapat membawa pendengarnya terlibat dengan isi cerita, serta dapat merasakan apa yang dirasakan oleh si karakter dalam cerita tersebut karena secara tidak sadar si pendengar dapat mengingat pengalaman yang mirip dengan cerita tersebut ataupun latar belakang cerita yang memiliki arti pribadi dengan dirinya. Orang lebih dapat mengingat sesuatu yang terjadi dengan dirinya daripada sesuatu yang terjadi dengan orang lain.

Cerita selalu dilingkupi dengan arti, serta terdiri dari penilaian moral, dan reaksi emosi kuat yang muncul dari pendengar cerita. Cerita, secara konkuren, dapat menjadi alat bantu mengingat dan cara untuk melupakan sesuatu, alat diagnostik dan pengalih perhatian, cara untuk kontrol sosial dan ekspresi kebebasan, hegemoni, dan subversive. Ketika narator menekankan plot, karakter, dan bermacam hubungan atribusi, pendengar kebanyakan cenderung mengingat detil dekoratif cerita, memotong, dan memutuskan hubungan antar cerita tersebut (Gherardi, Gabriel \& Brown, 2009). 
Boje (1991) melakukan penelitian tentang penggunaan cerita dalam organisasi menggunakan metode observasi partisipatif di sebuah perusahaan supply besar. la meneliti tentang bagaimana orang menggunakan cerita untuk mengartikan sebuah peristiwa/kejadian, memperkenalkan perubahan dan mendapatkan dukungan politik selama percakapan. Berdasarkan hasil penelitiannya ditemukan bahwa cerita tidak harus persis sama dengan konteks, diceritakan dari awal sampai akhir, seperti pada penelitian awal. Tetapi cerita lebih dinamis, beragam konteks, kadang-kadang pendek dan pendengar terlibat dalam jalan cerita, konteks dan implikasi dari cerita.

Parkin (Bullock, 2005) menyatakan bahwa cerita yang disampaikan memang mengandung pesan-pesan moral, tetapi tidak harus fokus pada pesan moral tersebut, karena yang paling ditekankan dalam cerita adalah menyampaikan pesan yang berhubungan dengan perubahan. Setelah pembacaan cerita partisipan diminta untuk bertanya atau berkomentar. Hal ini dilakukan untuk memperoleh refleksi dan untuk menggerakkan ide-ide tentang perubahan dari partisipan. Cerita dibuat singkat saja, sekitar beberapa paragraf, tetapi dibuat sebaik mungkin untuk menguraikan kekuatan pesan perubahan.

Perubahan adalah pengalaman dasar manusia yang konstan dan tidak dapat dihindarkan. Dalam perubahan, tekanan yang mengancam dapat berujud ketidakpasitan yang dihadapi, hasil tindakan yang tidak bisa diprediksi dan emosi yang menganggu. Cerita dan naratif membantu anggota dalam memahami, menjelaskan, mengelola, dan akhirnya menerima perubahan. Cerita membantu dalam memahami perubahan yang mengancam, dan mengatasinya dengan emosi.Cerita membahasakan perubahan dengan menuangkannya dalam kemungkinan yang dapat dipahami. Pemimpin atau agen perubahan yang lain mungkin dapat memulai perubahan organisasi dan sosial dengan memberikan cerita yang sesuai, cerita yang mencairkan batas, membuka kemungkinan, dan menstimulasi komitmen (Gherardi, Gabriel \& Brown, 2009). Cerita juga merupakan alat komunikasi yang sederhana, dan mudah dipahami karena orang bisa menyampaikan cerita secara alami tanpa harus belajar secara khusus. Cerita bisa lebih deskriptif, komprehensif, dan menawarkan penjelasan lengkap tentang perubahan yang dialami. Cerita mudah diingat orang, dan cerita dapat membawa pesan yang sulit membahasakannya ke dalam bahasa yang lebih mudah dipahami oleh pendengar.

Berdasarkan paparan di atas maka dapat ditarik kesimpulan bahwa penggunaan storytelling sangat baik untuk digunakan untuk menyampaikan pesan perubahan kepada karyawan karena melalui cerita pesan perubahan yang sulit diubah menjadi lebih sederhana sehingga memudahkan untuk dimengerti oleh pendengarnya. Cerita juga mudah diingat sehingga pesan perubahan yang disampaikan melalui cerita lebih mudah dipahami, dan lebih diingat oleh karyawan. Dengan tersampaikannya pesan perubahan dengan baik pada karyawan, maka diharapkan kesiapan untuk berubah 
karyawan pun meningkat. Untuk itu penelitian ini bertujuan untuk melihat pengaruh storytelling dalam meningkatkan kesiapan untuk berubah karyawan. Diharapkan dengan metode storytelling tingkat kesiapan karyawan untuk berubah akan meningkat.
Adapun hipotesis yang diajukan dalam penelitian ini adalah storytelling dapat meningkatkan kesiapan untuk berubah. Alur keterkaitan antara storytelling dan peningkatan kesiapan karyawan untuk berubah dapat dilihat pada gambar 1 .

Cerita membawa pendengarnya terlibat dengan isi cerita serta dapat merasakan apa yang dirasakan oleh si karakter dalam cerita tersebut sehingga pendengar lebih mudah memahami pesan yang disampaikan melalui cerita

Perubahan portofolio bisnis dari InfoComm menjadi TIME yang menyebabkan Perusahaan melakukan transformasi bisnis, transformasi infrastruktur, transformasi sistem dan model operasi serta transformasi sumber daya

Memotivasi karyawan agar keyakinan, sikap dan intensi karyawan positif terhadap perubahan yang sedang berlangsung
Lima komponen pesan perubahan belum tersampaikan dengan baik :

Discrepancy Efficacy Appropriates Principal Support Personal valence

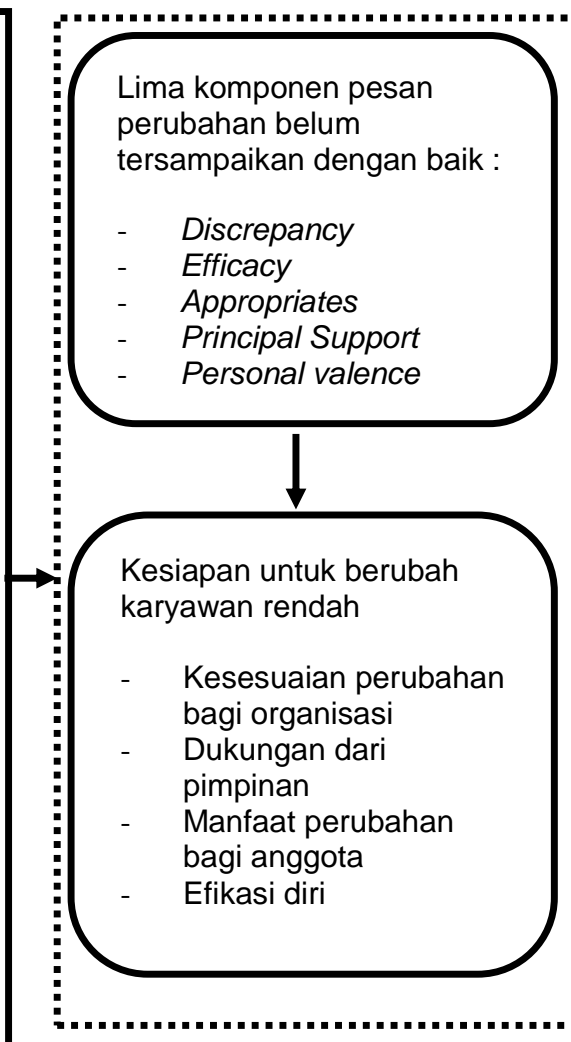

Kesiapan untuk berubah

Kesesuaian perubahan bagi organisasi

Dukungan dari

pimpinan bagi anggota

Efikasi diri
Lima komponen pesan perubahan :

Discrepancy

Efficacy

Appropriates

Principal

Support

Personal

valence

Kesiapan untuk berubah karyawan meningkat :
Kesesuaian perubahan bagi organisasi Dukungan dari pimpinan
Manfaat perubahan bagi anggota Efikasi diri

Gambar 1.Alur keterkaitan antara storytelling dan peningkatan kesiapan karyawan untuk berubah

\section{Keterangan}

$\longrightarrow$ : Menyebabkan

$\Longrightarrow$ : Intervensi

: Daerah yang dikenai intervensi 


\section{METODE PENELITIAN}

\section{Rancangan penelitian}

Desain eksperimen yang digunakan dalam penelitian ini adalah desain kelompok kontrol tidak diberi perlakuan dengan pengukuran awal-pengukuran ulang (Shadish, Cook \& Campbell, 2002).Desain eksperimen digambarkan dalam gambar 2 .

\begin{tabular}{|c|c|c|c|}
\hline Kelompok & Prates & Perlakuan & Pascates \\
\hline KE & Y1 & X & Y2 \\
\hline KK & Y1 & $-\mathrm{X}$ & Y2 \\
\hline
\end{tabular}

Gambar 2. Rancangan eksperimen

(Shadish, Cook \& Campbell, 2002)

Keterangan :

KE : Kelompok eksperimen (kelompok yang dikenai perlakuan)

KK : Kelompok kontrol (kelompok yang tidak dikenai perlakuan)

Y1 : Pengukuran Awal

Y2 : Pengukuran Akhir

$\mathrm{X}$ : Perlakuan (storytelling)

-X : Tanpa perlakuan

\section{Subjek}

Subjek penelitian adalah karyawan perusahaan telekomunikasi wilayah Jogjakarta. Pemilihan subjek ditentukan oleh pihak perusahaan yakni dilakukan berdasarkan departemen. Departemen yang dipilih sebagai subjek adalah departemen customer care sebagai kelompok kontrol dan departemen commerce sebagai kelompok eksperimen. Diperoleh 10 orang karyawan masuk ke dalam kelompok kontrol dan 10 orang masuk ke dalam kelompok eksperimen.

\section{Metode Pengambilan Data}

Data diambil dengan skala kesiapan untuk berubah. Pelaksanaan uji coba alat ukur dilakukan sekali yakni untuk menyeleksi aitem yang akan digunakan dalam skala yang dipakai untuk penelitian. Uji coba alat ukur dilakukan dengan menggunakan reliabilitas alpha Cronbah menghasilkan koefisien $\alpha=0,961$ untuk alat ukur kesiapan untuk berubah. Aitem yang lolos sebanyak 24 buah dan aitem yang gugur sebanyak 1 buah. Reliabilitas untuk alat ukur pesan perubahan diperoleh $\alpha=0,908$. Aitem yang lolos sebanyak 45 buah dan 5 aitem dinyatakan gugur. Uji validitas aitem dilakukan berdasarkan analisis rasional dengan penilaian profesional.

\section{Intervensi}

Intervensi yang dilakukan dalam penelitian ini adalah pemberian perlakuan berupa aktivitas storytelling. Storytelling ini bertujuan untuk menyampaikan lima komponen pesan perubahan di organisasi sehingga dengan tersampaikannya pesan perubahan akan meningkatkan kesiapan untuk berubah pada subjek.

Aktivitas storytelling dilakukan selama lima kali pertemuan dengan metode bercerita. Peserta diminta berkumpul di ruangan yang sudah disediakan dan diminta duduk membentuk lingkaran agar peserta dapat bertatap muka dengan peserta lainnya.Kemudian peserta diminta untuk mendengarkan sebuah cerita yang dibacakan oleh storyteller. Setelah cerita selesai dibacakan, peserta diminta memberikan respon pada cerita tersebut. Respon dapat berupa menambahi isi cerita, 
mengurangi isi cerita, menyim-pulkan isi cerita, menyimpulkan pesan moral dari cerita, dan menceritakan cerita baru, baik yang pernah dialami secara pribadi oleh peserta, maupun yang tidak peserta alami. Setiap peserta bebas memberikan responnya, dan dilakukan secara sukarela tanpa paksaan. Setelah peserta memberikan respon terhadap cerita, kemudian peserta diminta untuk menyimpulkan apa pesan moral dari cerita yang mereka bahas.

Bertindak sebagai storyteller adalah manager of commerce, selaku agen perubahan dalam organisasi. Manager of commerce mewakili manajemen menyampaikan pesan perubahan pada karyawan melalui cerita.

Setiap pertemuan membahas cerita yang berbeda. Cerita disiapkan oleh peneliti. Cerita yang disiapkan berisi tentang perubahan yang terjadi di kehidupan sehari-hari, maupun di organisasi. Hal ini dilakukan sebagai stimulus bagi peserta agar membandingkan perubahan yang ada dalam isi cerita dengan perubahan yang sedang ber-langsung di organisasi mereka.

Alur dan rincian dari kegiatan storytelling ini dikemas dalam sebuah modul yang sudah dipersiapkan oleh peneliti. Modul storytelling ini sebelumnya telah mengalami beberapa perbaikan melalui simulasi dan forum diskusi dengan rekanrekan mahasiswa magister profesi bidang Psikologi Industri dan OrganisasiProgram Pascasarjana Fakultas Psikologi Universitas Gadjah Mada.

\section{Prosedur Penelitian}

1. Persiapan Penelitian a. Penelitian pendahuluan

Guna lebih memahami kondisi perusahaan, peneliti melakukan wawancara awal dengan manager human resource perusahaan industri telekomunikasi wilayah Jogjakarta. Berdasarkan hasil wawancara disimpulkan bahwa masih banyak karyawan yang sulit berubah.Karyawan masih terbiasa dengan keadaan organisasi sebelum berubah. Mereka masih sulit diajak untuk mengikuti perubahan yang sedang berlangsung. Hal ini disebabkan oleh usia karyawan yang sudah hampir memasuki usia pensiun, gaji yang mencukupi meskipun hanya menduduki posisi biasa.

b. Penyusunan dan uji coba alat ukur Penyusunan alat ukur dilakukan oleh peneliti mengacu pada definisi kesiapan untuk berubah menurut Holt, Achilles, Hubert \& Stanley (2007) dan lima komponen pesan perubahan menurut Armenakis, Harris dan Field dalam Armenakis \& Harris (2002) sebagai cek manipulasi.

c. Penyusunan dan uji coba modul storytelling

Modul storytelling disusun oleh peneliti untuk menyampaikan lima komponen pesan perubahan kepada karyawan. Materi mengacu pada lima komponen utama pesan perubahan oleh Armenakis, Harris dan Field (Armenakis \& Harris, 2002). Pelaksanaan uji coba modul penelitian dilakukan kepada 16 orang mahasiswa magister psikologi profesi UGM, diminta untuk memberikan evaluasi terhadap materi dan proses kegiatan storytelling yang diberikan. Selain umpan balik dari peserta uji coba modul, materi 
storytelling juga dievaluasi dan mendapat masukan dari tiga orang mahasiswa Magister Profesi Psikologi.

Pemilihan subjek menggunakan metode purposive sampling, yaitu pengambilan sampel yang didasari tujuan tertentu (Arikunto, 1998). Kegiatan pemilihan subjek ini juga didasarkan atas diskusi dengan pihak perusahaan. Penugasan subjek dalam kelompok dilakukan dengan cara non-randomisasi. Dari awal penjajagan penelitian pihak perusahaan sudah menetapkan departemen mana yang boleh digunakan peneliti untuk dijadikan subjek penelitian. Peneliti diijinkan untuk mengambil data di dua departemen yaitu departemen customer care dan departemen commerce. Kemudian berdasarkan kesepakatan anta-ra peneliti, manager HRD dan manager dari kedua departemen yang digunakan untuk penelitian diputuskan untuk menetapkan departemen customer care sebagai kelompok kontrol dan departemen commerce sebagai kelompok eksperimen. Hal ini dilakukan untuk mempermudah penyusunan waktu berte-mu dengan subjek. Setelah ditentukan departemen mana yang jadi kelompok kontrol dan kelompok eksperimen, peneliti meminta kesediaan karyawan di masing-masing departemen untuk terlibat dalam penelitian ini.

d. Pembekalan storyteller

Pelaksanaan kegiatan storytelling dipandu oleh storyteller. Syarat menjadi storyteller adalah karyawan yang ditunjuk sebagai agen perubahan dalam organisasi. Dalam penelitian ini yang dipilih menjadi storyteller adalah manager commerce, karena manager commerce bertugas sebagai agen perubahan di departemen commerce. Sebelum memberikan storytelling, peneliti memberikan pembekalan kepada manager commerce selama satu hari. Pembekalan dilakukan dengan memberikan modul storyteller kepada manager commerce dan membahas modul tersebut dengan peneliti. Pada pelaksanaan storytelling, storyteller dibantu oleh tiga orang observer yang bertugas mengobservasi jalannya kegiatan storytelling. Observer memiliki kualifikasi pendidikan psikologi dan telah lulus praktek observasi serta telah diberikan pembekalan terlebih dahulu. Pembekalan dilakukan cara diskusi antara observer dengan peneliti. Observer diberikan modul storytelling, kemudian bersamasama dengan peneliti observer mendiskusikan isi modul tersebut.

\section{Pelaksanaan Penelitian}

\section{a. Pemberian inform consent} Inform consent menjelaskan tentang hal apa saja yang menjadi hak dan tanggung jawab peserta dan peneliti. Kemudian setelah peserta membaca dan isi dari inform consent yang diberikan oleh peneliti, peserta yang bersedia menjadi subjek diminta untuk menandatangani kesedian partisipasi dalam penelitian.

b. Pengukuran awal (prates)

Pelaksanaan pengukuran awal pada kelompok eksperimen dan kelompok kontrol yang menempati lokasi yang berbeda dilakukan dalam rentang waktu 3 hari. 
c. Pelaksanaan intervensi

Aktivitas storytelling dilakukan selama lima kali pertemuan dengan metode bercerita. Setiap pertemuan membahas sebuah cerita yang dibacakan oleh manager yang sudah dipilih sebagai agen perubahan di organisasi. Setelah manager selesai membacakan cerita subjek diminta untuk memberikan tanggapan terhadap cerita tersebut. Tanggapan dapat berupa menyimpulkan pesan moral cerita, mengemukakan cerita yang mirip dengan cerita yang sedang dibahas dan pengalaman pribadi subjek yang berhubungan dengan pesan moral cerita yang dibahas. Selama proses kegiatan storytelling didokumentasikan dalam bentuk rekaman dan foto. Isi pembicaraan subjek dalam rekaman ini akan digunakan sebagai data tambahan dalam menganalisis apakah proses yang berjalan sesuai dengan yang diharapkan. Kegiatan storytelling dilaksanakan dalam waktu 5 hri kerja kantor perusahaan telekomunikasi dimulai pada pukul 08.30-09.00 WIB selama lima kali pertemuan. Kegiatan storytelling diikuti oleh 10 orang peserta ditambah dengan seorang storyteller yaitu manager commerce.

\section{d. Pengukuran ulang (pascates)}

Pelaksanaan pengukuran ulang paska tes pada kelompok eksperimen dan kelompok kontrol dilaksanakan dengan waktu yang berbeda 3 hari kerja. Tujuan pengukuran ulang pascates ini adalah untuk mengetahui ada tidaknya peningkatan kesiapan untuk berubah dalam diri subjek setelah mendapatkan intervensi kegiatan storytelling.

\section{Analisis Data}

Analisis data yang digunakan dalam penelitian ini adalah analisis kuantitatif menggunakan statistik nonparametrik dengan metode tes Wilcoxon. Analisis kuantitatif dilakukan terhadap kedua pengukuran yaitu pra intervensi dan paska intervensi. Analisis ini dimaksudkan untuk mengetahui efektivitas intervensi storytelling terhadap peningkatan kesiapan karyawan untuk berubah, dengan menguji perbedaan kesiapan untuk berubah kelompok eksperimen yang mendapatkan intervensi storytelling dengan kelompok kontrol yang tidak mendapatkan intervensi, pada pengukuran pengukuran awal sebelum intervensi dan pengukuran ulang setelah intervensi. Sebagai tambahan atau pendukung dari analisis kuantitatif dilakukan analisis terhadap lembar kerja pendukung dan rekaman selama proses intervensi.

\section{HASIL PENELITIAN}

\section{Hasil Cek Manipulasi}

Cek manipulasi dilakukan guna memastikan pemahaman subjek di kelompok eksperimen terhadap materi yang disampaikan dalam storytelling. Cek manipulasi dilakukan dengan menggunakan skala. Skala ini diberikan sebelum storytelling dan setelah seluruh rangkaian proses storytelling selesai. Uji Wilcoxon 
Signed-Rank dilakukan untuk membandingkan rerata pesan perubahan pada pretest kelompok eksperimen dengan posttest kelompok eksperimen serta membandingkan rerata pre-test kelompok kontrol dengan post-test kelompok kontrol. Tabel 1 menunjukkan bahwa pada kelompok eksperimen terjadi peningkatan yang signifikan pada pemahaman mereka terhadap pesan perubahan sesudah storytelling $(\mathrm{z}=-2,547, \mathrm{p}<$ $0,05)$.

Tabel 1. Rangkuman Hasil Uji Beda Rerata Cek Manipulasi Kelompok Eksperimen Sebelum Storytelling (pre test) \& Sesudah Storytelling (post test)

\begin{tabular}{|c|c|c|c|c|c|c|c|}
\hline Waktu & Min & Maks & Rerata & SD & Z & Sig. & Keputusan \\
\cline { 1 - 4 } Prates & 103 & 174 & 150.9 & 22.58 & & & $\begin{array}{c}\text { Ada Perbedaan } \\
\text { Signifikan }\end{array}$ \\
\hline Paskates & 142 & 225 & 180 & 24.85 & $-2.547^{\mathrm{a}}$ & .011 & \\
\hline
\end{tabular}

Tabel 2 merupakan rangkuman hasil uji perbedaan rerata pada kelompok kontrol. Kelompok kontrol juga diberi skala pemahaman terhadap pesan perubahan dalam waktu yang bersamaan dengan pemberian skala pada kelompok eksperimen untuk memastikan bahwa peningkatan skor hanya terjadi pada kelompok yang menerima storytelling. Hasil uji Wilcoxon Signed-Rank dalam kelompok kontrol menunjukkan bahwa tidak terjadi perbedaan yang signifikan antara pre-test dan post-test pada skor pemahaman terhadap pesan perubahan $(z$ $=-, 968, p>0,05)$.

Tabel 2. Rangkuman Hasil Uji Beda Rerata Cek Manipulasi Kelompok Kontrol Sebelum Storytelling (pre test) \& Sesudah Storytelling (post test)

\begin{tabular}{|c|c|c|c|c|c|c|c|}
\hline Waktu & Min & Maks & Rerata & SD & Z & Sig. & Keputusan \\
\hline Pra Tes & 142 & 175 & 158.6 & 11.53 & & & $\begin{array}{c}\text { Tidak Ada } \\
\text { Perbedaan } \\
\text { Signifikan }\end{array}$ \\
\hline Paska Tes & 148 & 174 & 163 & 8.67 & $-.968^{\mathrm{a}}$ & .333 & \\
\hline
\end{tabular}

Uji Wilcoxon Signed-Rank dilakukan untuk membandingkan rerata pesan perubahan pada post-test kelompok eksperimen dengan post-test kelompok kontrol. Tabel 3 menunjukkan bahwa tidak terjadi perbedaan yang signifikan pada pemahaman terhadap pesan perubahan antara kelompok eksperimen dan kelompok kontrol $(z=-1,632, p>$ $0,05)$. 
Tabel 3. Rangkuman Hasil Uji Beda Rerata Cek Manipulasi Kelompok Kontrol Dan Kelompok Eksperimen setelah Pemberian Storytelling (Paska Tes)

\begin{tabular}{|c|c|c|c|c|c|c|c|}
\hline Kelompok & Min & Maks & Rerata & SD & $\mathbf{Z}$ & Sig. & Keputusan \\
\hline Kontrol & 148 & 174 & 163 & 8.67 & \multirow[b]{2}{*}{$-1.632^{\mathrm{a}}$} & \multirow[b]{2}{*}{.103} & Tidak Ada \\
\hline Eksperimen & 142 & 225 & 180 & 24.85 & & & $\begin{array}{c}\text { Perbedaan } \\
\text { Signifikan }\end{array}$ \\
\hline
\end{tabular}

Selain menggunakan skala, cek manipulasi juga dilakukan menggunakan lembar kerja yang diisi oleh subjek setiap kali pertemuan. Hasil lembar kerja subjek kemudian dianalisis secara kualitatif dan disumpulkan bahwa pesan perubahan tersampaikan dengan baik pada karyawan. Hal ini berarti bahwa cerita yang mampu menyampaikan pesan perubahan dengan baik kepada subjek serta mampu memunculkan emosi.

Hasil Uji Hipotesis. Uji Wilcoxon Signed-Rank dilakukan untuk memban- dingkan rerata pre-test kelompok eksperimen dengan post-test kelompok eksperimen sertamembandingkan rerata pre-test kelompok kontrol dengan post-test kelompok kontrol. Hasil uji Wilcoxon SignedRank menujukkan bahwa terjadi peningkatan skor kesiapan untuk berubah sebelum dan setelah storytelling secara signifikan pada kelompok eksperimen ( $\mathrm{z}=$ 2,197, $\mathrm{p}<0,05)$. Untuk lebih jelasnya lihat Tabel 4.

Tabel 4. Rangkuman Hasil Uji Wilcoxon Signed-Rank Kelompok Eksperimen

\begin{tabular}{|c|c|c|c|c|c|c|c|}
\hline Waktu & Min & Maks & Rerata & SD & $\mathbf{Z}$ & Sig. & Keputusan \\
\hline Pra Tes & 80.00 & 108 & 93.5 & 7.44 & \multirow[b]{2}{*}{$-2.197^{a}$} & \multirow[b]{2}{*}{.028} & \multirow[b]{2}{*}{$\begin{array}{c}\text { Ada Perbedaan } \\
\text { Signifikan }\end{array}$} \\
\hline Paska Tes & 96.00 & 110 & 104.7 & 3.97 & & & \\
\hline
\end{tabular}

Hasil uji Wilcoxon Signed-Rank dan post-test pada kelompok kontrol $(z=$ menunjukkan bahwa tidak terjadi $\left.-1,305^{a}, p>0,05\right)$. Untuk lebih jelasnya peningkatan secara signifikan pada skor lihat Tabel 5.

kesiapan untuk berubah antara pre-test

Tabel 5. Rangkuman Hasil Uji Wilcoxon Signed-Rank Kelompok Kontrol

\begin{tabular}{|c|c|c|c|c|c|c|c|}
\hline Waktu & Min & Maks & Rerata & SD & Z & Sig. & Keputusan \\
\hline Prates & 79 & 105 & 89 & 7.63 & & & $\begin{array}{l}\text { Tidak Ada } \\
\text { Perbedaan }\end{array}$ \\
\hline Paskates & 82 & 99 & 93.3 & 5.12 & $-1.305^{\text {a }}$ & .192 & \\
\hline
\end{tabular}


Berdasarkan hasil uji Wilcoxon Signed-Rank pada kelompok eksperimen didapatkan bahwa untuk empat dimensi kesiapan untuk berubah terjadi perubahan yang signifikan antara pre-test dan post- test. Uji Wilxocon Signed-Rank menunjukkan bahwa terjadi peningkatan kesiapan untuk berubah setelah storytelling (lihat Tabel 6).

Tabel 6. Rangkuman Hasil uji Wilcoxon Signed-Rank Dimensi Kesiapan Untuk berubah Kelompok Eksperimen

\begin{tabular}{|c|c|c|c|c|c|c|c|}
\hline \multirow{3}{*}{ Dimensi } & \multicolumn{4}{|c|}{ Waktu } & \multirow{3}{*}{$\mathbf{Z}$} & \multirow{3}{*}{ Sig. } & \multirow{3}{*}{ Keputusan } \\
\hline & \multicolumn{2}{|c|}{ Pra Tes } & \multicolumn{2}{|c|}{ Paska Tes } & & & \\
\hline & Rerata & SD & Rerata & SD & & & \\
\hline $\begin{array}{l}\text { Kebutuhan untuk } \\
\text { berubah }\end{array}$ & 19.7 & 2.86 & 22.4 & 1.07 & $-2.501^{a}$ & .012 & Ada Perbedaan \\
\hline $\begin{array}{l}\text { Manfaat } \\
\text { perubahan untuk } \\
\text { organisasi }\end{array}$ & 14 & 2 & 17.7 & .94 & $-2.816^{a}$ & .005 & Ada Perbedaan \\
\hline $\begin{array}{l}\text { Dukungan dari } \\
\text { pimpinan }\end{array}$ & 22.5 & 2.87 & 25.4 & 1.89 & $-1.995^{\mathrm{a}}$ & .046 & Ada Perbedaan \\
\hline $\begin{array}{l}\text { Manfaat } \\
\text { perubahan }\end{array}$ & 14.2 & 2.69 & 17.5 & .97 & $-2.717^{a}$ & .007 & Ada Perbedaan \\
\hline Efikasi diri & 18.6 & 2.22 & 21.7 & .67 & $-2.657^{a}$ & .008 & Ada Perbedaan \\
\hline
\end{tabular}

Berdasarkan hasil uji Wilcoxon Signed-Rank pada kelompok kontrol didapatkan bahwa untuk empat dimensi kesiapan untuk berubah, yaitu kesesuaian perubahan bagi organisasi yang meliputi dua aspek yaitu kebutuhan untuk berubah dan manfaat perubahan untuk organisasi, dukungan dari pimpinan, manfaat peru- bahan bagi anggota, dan efikasi diri tidak terjadi perubahan yang signifikan antara pre-test dan post-test.Uji Wilxocon Signed-Rank menunjukkan bahwa tidak terjadi peningkatan kesiapan untuk berubah setelah storytelling (lihat Tabel 7). 
Tabel 7. Rangkuman Hasil uji Wilcoxon Signed-Rank

Dimensi Kesiapan Untuk berubah Kelompok Kontrol

\begin{tabular}{|c|c|c|c|c|c|c|c|}
\hline \multirow{3}{*}{ Dimensi } & \multicolumn{4}{|c|}{ Waktu } & \multirow{3}{*}{$\mathbf{Z}$} & \multirow[b]{3}{*}{ Sig. } & \multirow[b]{3}{*}{ Keputusan } \\
\hline & \multicolumn{2}{|c|}{ Pra Tes } & \multicolumn{2}{|c|}{ Paska Tes } & & & \\
\hline & Rerata & SD & Rerata & SD & & & \\
\hline Kebutuhan untuk berubah & 19.7 & 2.86 & 19.7 & .948 & $-.641^{a}$ & .521 & $\begin{array}{l}\text { Tidak ada perbedaan yang } \\
\text { signifikan }\end{array}$ \\
\hline $\begin{array}{l}\text { Manfaat perubahan untuk } \\
\text { organisasi }\end{array}$ & 14 & 2 & 15.5 & 1.43 & $\begin{array}{c}- \\
1.546^{\mathrm{a}}\end{array}$ & .122 & $\begin{array}{l}\text { Tidak ada perbedaan yang } \\
\text { signifikan }\end{array}$ \\
\hline Dukungan dari pimpinan & 22.5 & 2.87 & 23.2 & 1.87 & $-.353^{\mathrm{a}}$ & .724 & $\begin{array}{l}\text { Tidak ada perbedaan yang } \\
\text { signifikan }\end{array}$ \\
\hline Manfaat perubahan & 14.2 & 2.69 & 15.4 & 1.77 & $\begin{array}{c}- \\
1.126^{\mathrm{a}}\end{array}$ & .260 & $\begin{array}{l}\text { Tidak ada perbedaan yang } \\
\text { signifikan }\end{array}$ \\
\hline Efikasi diri & 18.6 & 2.22 & 19.5 & 1.5 & $-.893^{\mathrm{a}}$ & .372 & $\begin{array}{l}\text { Tidak ada perbedaan yang } \\
\text { signifikan }\end{array}$ \\
\hline
\end{tabular}

\section{PEMBAHASAN}

Storytelling ini bertujuan untuk menyampaikan lima komponen pesan perubahan di organisasi sehingga dengan tersampaikannya pesan perubahan akan meningkatkan kesiapan untuk berubah pada subjek. Aktivitas storytelling dilakukan selama lima kali pertemuan dengan metode bercerita. Setiap pertemuan membahas sebuah cerita yang dibacakan oleh manager yang sudah dipilih sebagai agen perubahan di organisasi. Setelah manager selesai membacakan cerita, subjek diminta untuk memberikan tanggapan terhadap cerita tersebut. Tanggapan dapat berupa menyimpulkan pesan moral cerita, menceritakan cerita yang mirip dengan cerita yang sedang dibahas dan pengalaman pribadi subjek yang berhubungan dengan pesan moral cerita yang dibahas. Melalui intervensi storytelling, peneliti menyampaikan pesan perubahan yang dikemas dalam cerita-cerita yang dialami di kehidupan sehari-hari sehingga mudah dipahami oleh subjek.

Hasil pengujian hipotesis menunjukkan bahwa storytelling terbukti secara signifikan mampu menyampaikan pesan perubahan. Hal ini dapat dilihat dari peningkatan skor rerata pesan perubahan meningkat secara signifikan yaitu sebesar 29,1 poin pada kelompok eksperimen. Artinya intervensi yang berupa penggunaan storytelling berpengaruh signifikan untuk menyampaikan pesan perubahan pada pengukuran sesudah intervensi pada kelompok eksperimen. Hal ini sesuai dengan pendapat Denning (2001) yang menyatakan bahwa cerita membantu seseorang untuk memahami sesuatu yang kompleks karena cerita mudah diingat, tidak bersifat hirarki dan bersifat umum. Cerita juga mampu membawa orang pada pemahaman yang sama, berempati pada 
pengalaman orang lain dan akhirnya mampu mengubah persepsi seseorang.

Tetapi hasil yang berbeda ditemukan pada kelompok kontrol dan kelompok eksperimen setelah pemberian storytelling. Hasil analisis dengan menggunakan Wilcoxon Signed-Rank menunjukkan bahwa pemahaman terhadap pesan perubahan antara kelompok kontrol dan kelompok eksperimen tidak ada perbedaan yang signifikan $(z=-1,632$ dan $p$ $>0,05)$. Artinya intervensi yang berupa penggunaan storytelling tidak berpengaruh signifikan untuk menyampaikan pesan perubahan pada pengukuran sesudah intervensi. Hal ini mungkin disebabkan pada kelompok kontrol juga terjadi peningkatan rerata sejalan dengan peningkatan rerata pada kelompok eksperimen. Peningkatan rerata pada kelompok kontrol yang pada kenyataannya tidak diberikan perlakukan dapat disebabkan program sosialisasi perubahan organisasi yang diadakan oleh pihak perusahaan. Sosialisasi yang dilakukan oleh pihak perusahaan melalui web kantor dan pemutaran siaran televisi yang berisi tentang perubahan yang sedang berlangsung di organisasi mereka. Mengingat kelompok kontrol berada di kantor pusat untuk wilayah Yogyakarta, dimana di kantor pusat tersebut setiap hari diputar siaran yang berisi tentang perubahan yang sedang terjadi di perusahaan. Sedangkan kelompok ekspe-rimen bekerja di kantor cabang. Di kantor cabang tidak ada pemutaran tayangan tentang perubahan yang sedang berlangsung di organisasi mereka.

Hal lain yang menyebabkan tidak ada perbedaan yang signifikan antara kelompok kontrol dan kelompok eksperimen pada pemahaman terhadap pesan perubahan setelah intervensi adalah masalah waktu. Peningkatan rerata kelompok eksperimen tidak berbeda secara signifikan dengan rerata kelompok kontrol setelah intervensi bisa jadi disebabkan jangka waktu antara pre-test dan post-test yang singkat. Hal ini sejalan dengan pendapat Fox dan Boulton (2003) yang menyatakan bahwa waktu yang lebih panjang diperlukan untuk mengubah sebuah situasi sosial yang kaku atau telah terbentuk.

Kegiatan storytelling diberikan kepada karyawan yang masuk dalam kelompok eksperimen dengan metode mendengarkan cerita dan merespon cerita. Sebelum diberikan intervensi, dilakukan pengukuran awal kesiapan untuk berubah pada kelompok eksperimen dan kelompok kontrol, dan dua minggu setelah selesai intervensi kembali dilakukan pengukuran akhir pada kesiapan untuk berubah anstar kedua kelompok. Hasil analisis kuantitatif menunjukkan bahwa ada perbedaan yang signifikan pada kesiapan untuk berubah antara kelompok eksperimen dan kelompok kontrol pasca intervensi. Hal tersebut berarti intervensi storytelling berpengaruh secara signifikan untuk meningkatkan kesiapan untuk berubah pada karyawan perusahaan. 
Hasil di atas sejalan dengan penelitian yang dilakukan oleh Armenakis dan Harris (2002) yang menyatakan bahwa kesiapan untuk berubah diciptakan dalam penyampaian pesan perubahan dari managemen kepada karyawan dimana pesan perubahan tersebut akan menjawab ketidakpastian dalam diri anggota organisasi. Hal ini diperkuat oleh Elving (2005) yang menyatakan bahwa komunikasi yang efektif dapat memengaruhi kesiapan melalui peran informasi tentang perubah-an, menciptakan semangat komunitas dan mengurangi tingkat ketidakpastian dan perasaan tidak aman atas pekerjaan. Klein (1996) juga menyatakan bahwa komunikasi tatap muka dengan penerima pesan perubahan lebih efektif digunakan untuk menyampaikan pesan perubahan. Komunikasi dan interaksi antara implementator dan penerima perubahan dibutuhkan untuk menjadikan perubahan menjadi nyata. Bersama-sama mereka mendiskusikan konsekuensi praktis dan usaha-usaha apa yang dibutuhkan untuk mendukung perubahan. Kolaborasi dalam perubahan akan mendorong ke respon yang positif terhadap perubahan tersebut (Weick \& Quinn, 1999) dan orang-orang akan lebih antusias dan komit terhadap perubahan (Chawla \& Kelloway, 2004).

\section{SIMPULAN DAN SARAN}

\section{Simpulan}

Berdasarkan hasil penelitian ditemukan bahwa storytelling efektif untuk menyampaikan pesan perubahan pada karyawan. Karena pesan perubahan sampai pada karyawan dengan baik, maka kesiapan untuk berubah karyawan juga meningkat secara signifikan. Jadi dapat disimpulkan bahwa penggunaan storytelling efektif untuk meningkatkan kesiapan untuk berubah pada karyawan.

\section{Saran}

Ada sejumlah saran yang perlu peneliti sampaikan. Pertama: Saran untuk praktisi dan perusahaan. Penggunaan storytelling terbukti efektif untuk meningkatkan kesiapan berubah karya-wan. Melalui storytelling pesan perubaha dapat disampaikan secara efektif kepada karyawan sehingga karyawan memperoleh informasi yang lengkap dan dukungan dalam menghadapi perubahan yang terjadi di organisasi mereka sehingga karyawan dapat ikut terlibat dan mendukung perubahan yang berlangsung di organisasi.Program ini dapat dilakukan 15 menit sebelum bekerja setiap harinya. Karyawan berkumpul dan membicarakan tentang cerita-cerita sehari-hari yang akan dihubungkan dengan perubahan yang sedang berlangsung di organisasi berdasarkan sudut pandang masing-masing karyawan. 
Kedua: Saran untuk penelitian selanjutnya. Bagi peneliti yang tertarik untuk meneliti pengaruh storytelling dalam organisasi, ada beberapa hal yang harus diperhatikan agar tidak berpotensi mencemari proses maupun hasil penelitian. Beberapa hal tersebut diantaranya: (1) Karakteristik subjek penelitian. Penentuan karakteristik subjek penelitian sebaiknya diperketat, disarankan untuk penelitian selanjutnya proses seleksi karakteristik subjek diperketat dengan membatasi pada karyawan yang memiliki tingkat kesiapan untu berubah yang rendah - sedang saja. (2) Kontrol terhadap variabel lain. Intervensi berupa cerita yang dibacakan oleh storyteller dipengaruhi juga oleh faktor internal subjek, maka faktor-faktor, antara lain: daya tangkap subjek dalam menangkap isi dan menyimpulkan cerita, perbedaan gaya belajar, usia, dapat dikontrol. Variabel eksternal seperti program sosialisasi perubahan atau yang sejenis dapat ditunda selama pelaksanaan eksperimen berlangsung. (3) Isi cerita. Cerita yang nyata yang pernah terjadi di organisasi dan langsung dialami oleh subjek akan lebih mampu menggugah emosi, dan terekspresikan dalam keterlibatan subjek dalam cerita tersebut.

\section{DAFTAR PUSTAKA}

Armenakis, A. A., \& Harris, S. G. (2002).Crafting a change message to create transformational readiness.
Journal of Organizational Change Management, 15(2), 169-183.

Armenakis, A. A., Harris, S. G., \& Mossholder, K. W. (1993). Creating readiness for organizational change. Human Relations, 46, 681-703.

Ashford, S. J. (1988). Individual Strategies for Coping with Stress During Organizational Transitions. The Journal of Applied Behavioral Science, 24 (1), 19-36.

Beer, M. \& Nohria, N. (2000).Cracking the Code of Change. Harvard Business Review. May-June, 133141.

Boje, D.M. (1991). The Storytelling Organization: A Study of Story Performance in an Office-Supply Firm. Administrative Science Quarterly, 36 (1), 106-126

Bullock, J. (2005).Tales for Change: Using Storytelling to Develop People and Organizations. Books Review, Leadership \& Organization Development Journal, 26 (8).

Charles, A. C, \& Shivers-Blackwell, S. L. (2006). Ready, set, go: examining student readiness to use ERP technology. Journal of Management Development, 25 (8), 795-805.

Chawla, A., \& Kelloway, E. K. (2004).Predicting openness and commitment to change. The Leadership \& Organization Development Journal, 25(6), 485-498. 
Chonko, L.B. (2004). Organizational readiness for change, individual fear of change, and sales manager performance: an empirical investigation. Journal of PersonalSelling and Sales Management, 24 (1), 717.

Cummings, T.G. \& Worley, C.G. (2005). Organization Development and Change. 6th Ed. South-Western College Publishing.

Cunningham, C. E., Woodward, C. A., Shanonn, H. S., Maclntosh, J., Lendrum, B., Rosenbloom, D., \& Brown, J. (2002). Readiness for Organizational Change: A Longitudinal Study Workplace, Psychological and Behavioral Correlates. Journal of Occupational and Organizational Psychology, 75, 377-392.

Devos, G., Vanderheyden, K., \& Broek, H. D. (2002).A Framework for Assesing Commitment to Change. Process and Context Variables of Organizational Change. Vlerick Working Papers. Vlerick Leaven Gent Management School.

Elving, W. J. L. (2005). The Role of Communication in Organizational Change, Corporate Communications.An International Journal, 10 (2).

Gherardi, S., Gabriel, Y.,\& Brown, A. D. (2009). Storytelling and change: an unfolding story. Organization, 16(3), 323-333.

Gumus, M. (2007).The effect of communication on knowledge sharing in organizations. Journal of Knowledge Management Practice, $8(2)$.

Holt, D. T., Achilles, A. A., Hubert, S. F., \& Stanley, G. H. (2007). Readiness for Organizational Change: The Systematic Development of a Scale. Journal of Applied Behavioral Science,43, 232

Klein, S. M. (1996). A management communication strategy for change. Journal of Organizational Change Management, 9, 32-46.

Kotter, J. P. (1995). Leading change: Why transformation effort fail. Harvard. Bussness Review, 73(2), 59-67.

Kreitner, R \& Kinicki, A. (2001). Organizational Behavior. New York: McGraw Hill.

Luecke, R. (2003). Managing Change and Transition. Boston: Harvard Business School Press

Shadish, W. R., Cook, T. D., \& Campbell, D.T. (2002).Experimental and quasiexperimental designs for generalized causal inference. Boston: HoughtonMifflin Company.

Sugiharto, (2005).Strategi Transformasi dan Reformasi BUMN menjadi Korporasi Berdaya Saing untuk Pening- 
katan Perekonomian Nasional. Weick, K. E., \& Quinn, R. E. Makalah yang tidak dipublikasikan (1999).Organizational change and yang diajukan untuk seminar di development. Annual Review of UGM, Yogyakarta. Psychology, 50, 361-386. 